\title{
Awareness and Attitude of Married Women toward Emergency Contraception
}

\author{
Amany H. Abd Elrahim, Manal F. Moustafa \& Hala A. El Fattah.
}

Assistant lecturer of obstetrics and Gynecological Nursing- Faculty of Nursing- El Minia University, Egypt. Professor of obstetrics and Gynecological Nursing - Faculty of Nursing- Assiut University, Egypt.

Lecturer of obstetrics and Gynecological Nursing- Faculty of Nursing-Kafr El Sheikh University, Egypt.

\begin{abstract}
Introduction: Emergency contraception (EC) refers to contraceptive methods that a woman can use in her last chance after unprotected sexual intercourse (UPSI) whether consensual, as result of sexual assault or after failure or incorrect use of other methods to prevent unintended pregnancy. Aim of this study: Assess the awareness and attitude of married women toward emergency contraception. Subject and method: A descriptive research design was utilized in this study. Six hundred women were recruited for the study. Data were collected from El Minia University Hospital for women and children from Obstetrics, Gynecology department in El Minia City using structured interviewing questionnaire. Result: the study revealed that near two third (62.9\%) of the women had a poor knowledge about emergency contraception and more than half $(53.5 \%)$ of them had positive attitude toward EC. Conclusion: in spite of a greater percentage of women heard about emergency contraception they had a poor knowledge about it and near half of the studied women had a positive attitude regarding it. Recommendation: There is a need to raise awareness about emergency contraceptives as an option with other contraception methods and revitalizing of the family education program for disseminating similar information.
\end{abstract}

\section{Keywords: Emergency Contraception, Awareness, Attitude, \& Women.}

\section{Introduction}

Family planning is critical for the health of women and their families and it can accelerate a country's progress toward reducing poverty and achieving development goals. Because of its importance, universal access to reproductive health services including family planning is identified as one of the targets of the United Nations Millennium Development Goals (MDGs) (UNMDGs, 2012). Moreover, other international agreements including the program of action of the 1994 international and development promote individuals' freedom to decide the number and timing of their children as a basic human and reproductive right (United Nations, 2012).

In Egypt: $14 \%$ of all pregnancies are unintended (Bradley, et al, 2011). One particularly harmful consequence of unintended pregnancy is unsafe abortion which the World Health Organization (WHO) defines as a procedure for terminating a pregnancy carried out by individuals lacking the necessary skills or in an environment not conforming to minimal medical standards or both (WHO, 2011). Women who decide to terminate their unintended pregnancy may resort to unsafe abortion especially if they face legal barriers to obtaining a safe abortion as the case in most of the Arab region (Dabash, et al., 2008). According to WHO nearly 1 million unsafe abortions were performed in 2008 in countries of northern Africa alone. Complications of these abortions accounted for 12 percent of maternal deaths in that region (WHO, 2011).

Emergency contraception (EC) refers to contraceptive methods that a woman can use in her last chance after unprotected sexual intercourse (UPSI) whether consensual, as result of sexual assault or after failure or incorrect use of other methods to prevent unintended pregnancy (Trussell et al, 2014). Emergency contraceptions are a type of family planning methods that provide a safe and effective means of post coital treatment and have been estimated to prevent at least $75 \%$ of expected pregnancies resulting from unprotected intercourse. Unintended pregnancy is a global problem, which affects women, their families and society at large. Abortion is a frequent consequence and about 50 million pregnancies terminated each year (Kazi, 2000).

Situations of unprotected intercourse where EC can be used as a backup contraceptive method include, failure of barrier methods such as slippage, breakage or misuse of the condom, sexual assaults, rape, failed coitus interrupts, two or more consecutive missed oral contraceptive pills, or simply because intercourse was unexpected and therefore contraception had not been used (Ebuehi et al., 2006). Worldwide unplanned pregnancy is a major medical, social, and public health problem (Kang et al., 2008). There are 80 million unplanned pregnancies in the world every 
year, of which $38 \%$ of all pregnancies can be deemed an epidemic (Glasier, et al., 2006).

Emergency contraception is the postcoital method of pregnancy prevention. Three methods of EC are used: (1) levonorgestrel-only pills (LNG), or progestin only pills (Plan B) (2) combined estrogen and progestin pills (the Yuzpe regimen) and (3) the copper intrauterine device. There are another forms of emergency contraception have been clinically used as Danazol, Mifepristone, and high dose estrogens (Langston, 2010).

EC pills are currently available in three forms: a progestin only method marketed under the brand name plan B (two tablets of $0.75 \mathrm{mg}$ levonorgestrel taken together, available in Egypt under brand name contraplan II) (Cheng, et al., 2008) and a combined hormonal method, also known as the Yuzpe regimen, which is dispensed in the form of multiple birth control pills. A third form contains an antiprogestin (either Mifepristone or ulipristal acetate; a secondgeneration progesterone receptor modulator; (Dunn, et al, 2003), but it is not currently available in Egypt.

\section{Significance of the study}

The major factor limiting the use of EC may be inadequate information about their effectiveness and availability or unfavorable opinions about their safety due to misinformation. Despite the fact that different modern contraceptives exist in Egypt, the problem of unintended pregnancy still exist which could be due to gap in awareness and negative attitudes towards contraception.

\section{Aim of the study}

To assess the awareness and attitude of married women toward emergency contraception

\section{Research Question}

Did married women have awareness and positive attitude toward emergency contraception?

\section{Materials \& methods}

\section{Research design}

A descriptive research design was utilized in carrying out this study.

\section{Study Settings}

The study was conducted in El Minia University Hospital for women and children, Obstetrics, Gynecology department (Outpatient clinics and inpatient unit). This hospital provides free services to women who are resident in El Minia city and other villages.

\section{Sample size}

A convenient sample was included in the study. The study was carried for 6 months from March, through
August, 2013. The sample of the present study included six hundred women.

The target population of the study was chosen according to the following criteria

Inclusion criteria

- Married woman in reproductive age from (15-49) years .

- Woman from urban and rural areas.

- Different level of education

- Pregnant, postpartum or post abortion woman.

Tool of data collection

A structured interview questionnaire was developed, modified, translated and utilized by the researcher to collect the necessary data to assess the awareness and attitude about emergency contraceptions based upon a review of literature and similar studies conducted elsewhere and it was reviewed by experts from obstetrics and Gynecological nursing specialties. The Questionnaire included three parts:

The first part included sociodemographic characteristics and history of the women as age, age at marriage, residence, level of education, occupation and history of unwanted pregnancy.

The second part included questions to assess the women's awareness about emergency contraceptions. It was determined by using multiple-choice questions. The questions were evaluated the level of knowledge about emergency contraceptions. It was included 20 questions. Each correct question corresponded to 1 point, and so there was a total of 20 points for twenty questions. Woman knowledge was graded as: ( $\geq 14$ Good), (8-13 Moderate) and ( $\leq 7$ Poor).

The third part included questions to evaluate women's attitude toward EC. The woman attitudes were measured using 14 items rated on a three point likert scale as agree, neutral and disagree. Using this three-point scale for 14 questions it considers the maximum score for each respondent at 42 and the minimum at 14. A high score (29-42 degree) will indicate a positive attitude while a low score (14-28 degree) will indicate a negative attitude.

\section{Administrative approval}

Before conducting the study an official permission was taken from the Dean of Faculty of Nursing, El Minia University and the director of El Minia University Hospital for women and children also an official permission was taken the head of Obstetrics and Gynecology department. An oral informed consent was obtained from included women in the study. It included full explanation of the procedure, and rights for privacy and confidentiality. .

\section{Ethical consideration}

Research proposal approved from ethical committee in the faculty of nursing. There is no risk for study subjects during application of the study. An oral 
consent was obtained from women and nurses after explaining the nature and purpose of the study. Confidentiality and anonymity were assured.

\section{Pilot study}

Pilot study was done on (10\% of the duration which equal 3 weeks at this period 60 women were collected) to assess the applicability of the tool, and was excluded from the study sample, According to the results of the pilot, tools modifications were done therefore, the rewording or rephrasing of statements was done. It also helped in the estimation of the time needed to fill the form.

\section{Field work}

The researcher collected the sample through three days per week from the beginning of the study. The field work lasted for six months from March through August, 2013. The researcher attended to the hospital at 9:00 a.m, to 2:00 p.m, after introducing herself to the eligible woman, the purpose and nature of the study were explained to every woman who participate in the study, Face to face interview was done through structured questionnaire about the awareness and attitude toward emergency contraception in order to collect the data. The interview to filling the questionnaire and health education took 35-40 minutes. Eight to nine women were recruited each day.

\section{Limitations of the study}

The current study had exhausted every effort to fulfill the study; however there were some unavoidable limitations. Some of the women refused to participated in this study because they were busy so, the researcher make more clarification for purpose of the study and give more education about emergency contraception and its importance and this attract women to initiate and participate in the study and this take more effort for the researcher.

\section{Statistical analysis}

Data were analyzed using the statistical package for social science (SPSS) (Windows Microsoft). Continuous data were expressed as frequency, percentage; mean and SD. discrete data were expressed as frequency and percentage. Comparison between variables was done using chi-square test. Probability (p-value) less than 0.05 was considered significant and less than 0.001 was considered highly significant. 


\section{Results}

Table (1): Distribution of the women according to their sociodemographic characteristics.

\begin{tabular}{|c|c|c|}
\hline Socio- demographic characteristics & $(\mathrm{N}=600)$ & $\%$ \\
\hline 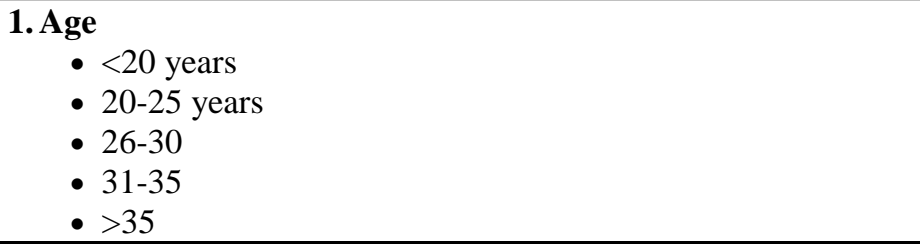 & $\begin{array}{c}96 \\
138 \\
157 \\
95 \\
114 \\
\end{array}$ & $\begin{array}{l}16.0 \\
23.0 \\
26.2 \\
15.8 \\
19.0\end{array}$ \\
\hline Mean age \pm SD & & \\
\hline $\begin{array}{l}\text { 2. Age at marriage } \\
\text { - } 15-<20 \\
\text { - } 20-<25 \\
\text { - }>25\end{array}$ & $\begin{array}{c}300 \\
246 \\
54\end{array}$ & $\begin{array}{c}50.0 \\
41.0 \\
9.0\end{array}$ \\
\hline Mean age \pm SD & & \\
\hline $\begin{array}{l}\text { 3. Residence } \\
\text { - Urban } \\
\text { - Rural }\end{array}$ & $\begin{array}{l}242 \\
358\end{array}$ & $\begin{array}{l}40.3 \\
59.7\end{array}$ \\
\hline $\begin{array}{l}\text { 4. Mother's educational level } \\
\text { - Illiterate } \\
\text { - Read and write } \\
\text { - secondary } \\
\text { - University or higher }\end{array}$ & $\begin{array}{c}78 \\
126 \\
228 \\
168\end{array}$ & $\begin{array}{l}13.0 \\
21.0 \\
38.0 \\
28.0\end{array}$ \\
\hline $\begin{array}{l}\text { 5. Mother's occupation } \\
\text { • House wife } \\
\text { - Employed }\end{array}$ & $\begin{array}{l}341 \\
259\end{array}$ & $\begin{array}{l}56.8 \\
43.2\end{array}$ \\
\hline
\end{tabular}

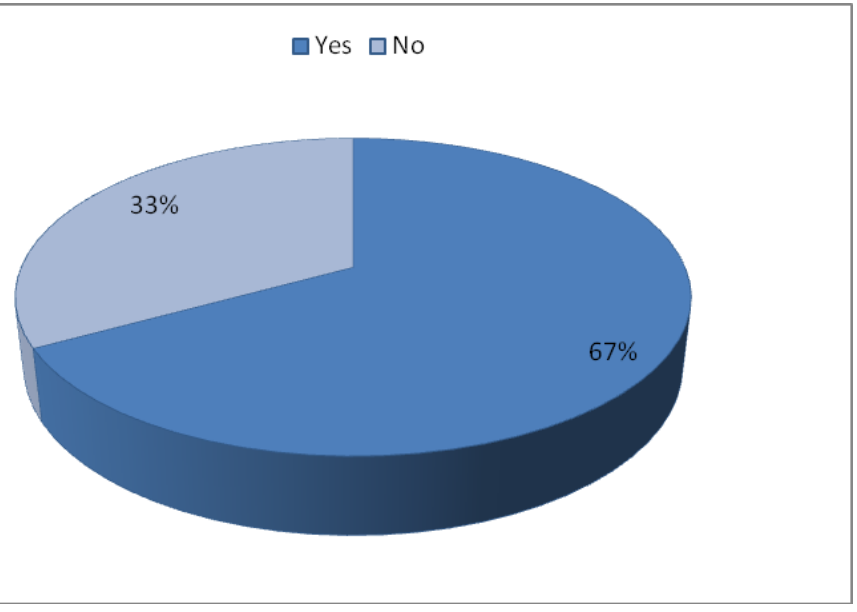

Figure (1) Distribution of the women according to the presence of unwanted pregnancy in the pas 
Table (2): Distribution of the women according their knowledge about emergency contraception methods.

\begin{tabular}{|c|c|c|}
\hline Knowledge about emergency contraception methods & $(\mathrm{N}=600)$ & $\%$ \\
\hline $\begin{array}{l}\text { 1. Ever heard about emergency contraception }(\mathbf{n}=\mathbf{6 0 0}) \\
\text { - Yes } \\
\text { - No }\end{array}$ & $\begin{array}{l}456 \\
144\end{array}$ & $\begin{array}{l}76.0 \\
24.0\end{array}$ \\
\hline $\begin{array}{l}\text { 2.Source of information }(\mathbf{n}=\mathbf{4 5 6}) \\
\text { - Media } \\
\text { - Family and friends } \\
\text { - Health personnel(Doctors, Nurses and Pharmacists) } \\
\text { - All of the above }\end{array}$ & $\begin{array}{c}171 \\
189 \\
88 \\
8\end{array}$ & $\begin{array}{r}37.5 \\
41.4 \\
19.3 \\
1.8\end{array}$ \\
\hline $\begin{array}{l}\text { 3. Mechanism of action of emergency contraception } \\
\text { - Prevent ovulation } \\
\text { - Prevent fertilization } \\
\text { - Prevent implantation } \\
\text { - All of the above } \\
\text { - Don't know } \\
\end{array}$ & $\begin{array}{c}54 \\
36 \\
42 \\
42 \\
282 \\
\end{array}$ & $\begin{array}{r}11.8 \\
7.9 \\
9.2 \\
9.2 \\
61.8 \\
\end{array}$ \\
\hline $\begin{array}{l}\text { 4. When emergency contraception generally recommended? } \\
\text { - After unprotected sexual intercourse } \\
\text { - After missed pills } \\
\text { - After failure of any method like broken condom } \\
\text { - All of above } \\
\text { - Don't know }\end{array}$ & $\begin{array}{c}56 \\
70 \\
54 \\
84 \\
192\end{array}$ & $\begin{array}{l}12.3 \\
15.4 \\
11.8 \\
18.4 \\
42.1\end{array}$ \\
\hline $\begin{array}{l}\text { 5. Are Oral Contraceptive pills used as EC? } \\
\text { - Yes } \\
\text { - No } \\
\text { - Don't know }\end{array}$ & $\begin{array}{c}212 \\
85 \\
159\end{array}$ & $\begin{array}{l}46.5 \\
18.6 \\
34.9\end{array}$ \\
\hline $\begin{array}{l}\text { 6. How long after intercourse can ECPs work? } \\
\text { - } 72-120 \text { hours after intercourse } \\
\text { - } 48 \text { hours after intercourse } \\
\text { - } 24 \text { hours after intercourse } \\
\text { - Before intercourse } \\
\text { - Don't known }\end{array}$ & $\begin{array}{c}42 \\
60 \\
62 \\
76 \\
216\end{array}$ & $\begin{array}{r}9.2 \\
13.2 \\
13.6 \\
16.7 \\
47.4\end{array}$ \\
\hline $\begin{array}{l}\text { 7. How many numbers of doses are recommended from ECPs? } \\
\text { - Single dose } \\
\text { - Double doses } \\
\text { - Triple doses } \\
\text { - Don't know }\end{array}$ & $\begin{array}{c}88 \\
171 \\
8 \\
189\end{array}$ & $\begin{array}{r}19.3 \\
37.5 \\
1.8 \\
41.4\end{array}$ \\
\hline $\begin{array}{l}\text { 8. What is the interval between doses of ECPs? } \\
\text { - } 12 \text { hours } \\
\text { - } 24 \text { hours } \\
\text { - Don't know }\end{array}$ & $\begin{array}{l}135 \\
57 \\
264\end{array}$ & $\begin{array}{l}29.6 \\
12.5 \\
57.9\end{array}$ \\
\hline $\begin{array}{l}\text { 9. Are ECPs methods act as abortifacient? } \\
\text { - Yes } \\
\text { - No } \\
\text { - Don't know }\end{array}$ & $\begin{array}{l}78 \\
166 \\
212\end{array}$ & $\begin{array}{l}17.1 \\
36.4 \\
46.5\end{array}$ \\
\hline $\begin{array}{l}\text { 10. Is copper IUDs used as EC? } \\
\text { - Yes } \\
\text { - No } \\
\text { - Don't know }\end{array}$ & $\begin{array}{l}76 \\
116 \\
264\end{array}$ & $\begin{array}{l}16.7 \\
25.4 \\
57.9\end{array}$ \\
\hline
\end{tabular}


Table (3): Distribution of the women according to their level of knowledge about emergency contraception methods

\begin{tabular}{|c|c|c|}
\hline Level of knowledge about emergency contraception methods & No & $\begin{array}{c}\text { \% } \\
(\mathbf{1 0 0})\end{array}$ \\
\hline Poor level ( $\mathbf{4}$ (4) & 287 & 62.9 \\
\hline Moderate level (8-13) & 105 & 23.0 \\
\hline Good level $(\geq \mathbf{1 4 )}$ & 64 & 14.1 \\
\hline
\end{tabular}

Table (4): the relationship between sociodemographic characteristics of the women and their knowledge about emergency contraception methods

\begin{tabular}{|c|c|c|c|c|c|c|c|c|c|c|}
\hline \multirow{3}{*}{$\begin{array}{l}\text { Sociodemographic } \\
\text { characteristics }\end{array}$} & \multirow{2}{*}{\multicolumn{2}{|c|}{ Total No }} & \multicolumn{6}{|c|}{ Level of knowledge } & \multirow{3}{*}{$\mathbf{X}^{2}$} & \multirow{3}{*}{$\begin{array}{c}\text { P. } \\
\text { Value }\end{array}$} \\
\hline & & & \multicolumn{2}{|c|}{$\leq 7$ poor } & \multicolumn{2}{|c|}{$\begin{array}{c}8-13 \\
\text { moderate }\end{array}$} & \multicolumn{2}{|c|}{$\geq 14$ Good } & & \\
\hline & $\begin{array}{c}n= \\
456\end{array}$ & $\%$ & $\begin{array}{l}n= \\
287\end{array}$ & $\%$ & $\begin{array}{l}n= \\
105\end{array}$ & $\%$ & $\begin{array}{l}n= \\
64\end{array}$ & $\%$ & & \\
\hline $\begin{array}{l}\text { 1. Age } \\
\text { - }<20 \mathrm{yrs} \\
\text { - } 20-25 \mathrm{yrs} \\
\text { - } 26-30 \mathrm{yrs} \\
\text { - } 31-35 \mathrm{yrs} \\
\text { - }>35 \mathrm{yrs}\end{array}$ & $\begin{array}{c}60 \\
101 \\
115 \\
83 \\
97\end{array}$ & $\begin{array}{l}13.2 \\
22.1 \\
25.2 \\
18.2 \\
21.3\end{array}$ & $\begin{array}{l}37 \\
61 \\
67 \\
58 \\
64\end{array}$ & $\begin{array}{l}12.9 \\
21.3 \\
23.3 \\
20.2 \\
22.3\end{array}$ & $\begin{array}{l}16 \\
25 \\
26 \\
11 \\
27\end{array}$ & $\begin{array}{l}15.2 \\
23.8 \\
24.8 \\
10.5 \\
25.7\end{array}$ & $\begin{array}{c}7 \\
15 \\
22 \\
14 \\
6\end{array}$ & $\begin{array}{c}10.9 \\
23.4 \\
34.4 \\
21.9 \\
9.4\end{array}$ & 13.346 & 0.100 \\
\hline $\begin{array}{l}\text { 2. Residence } \\
\text { - Urban } \\
\text { - Rural }\end{array}$ & $\begin{array}{l}206 \\
250\end{array}$ & $\begin{array}{l}45.2 \\
54.8\end{array}$ & $\begin{array}{l}117 \\
170\end{array}$ & $\begin{array}{l}40.8 \\
59.2\end{array}$ & $\begin{array}{l}53 \\
52\end{array}$ & $\begin{array}{l}50.5 \\
49.5\end{array}$ & $\begin{array}{l}36 \\
28\end{array}$ & $\begin{array}{l}56.3 \\
43.7\end{array}$ & 6.613 & $0.04^{*}$ \\
\hline $\begin{array}{l}\text { 3. level of } \\
\text { education } \\
\text { - Illiterate } \\
\text { - Read and } \\
\text { write } \\
\text { - Secondary } \\
\text { - University or } \\
\text { higher }\end{array}$ & $\begin{array}{c}54 \\
84 \\
186 \\
132\end{array}$ & $\begin{array}{l}11.8 \\
18.4 \\
40.8 \\
28.9\end{array}$ & $\begin{array}{c}50 \\
73 \\
121 \\
43\end{array}$ & $\begin{array}{l}17.4 \\
25.4 \\
42.2 \\
15.0\end{array}$ & $\begin{array}{c}3 \\
10 \\
48 \\
44\end{array}$ & $\begin{array}{c}2.9 \\
9.5 \\
45.7 \\
41.9\end{array}$ & $\begin{array}{c}1 \\
1 \\
17 \\
45\end{array}$ & $\begin{array}{c}1.6 \\
1.6 \\
26.6 \\
70.3\end{array}$ & 109.653 & $<0.001^{* *}$ \\
\hline $\begin{array}{l}\text { 4. Occupation } \\
\text { - House wife } \\
\text { - Employed }\end{array}$ & $\begin{array}{l}257 \\
199\end{array}$ & $\begin{array}{l}56.4 \\
43.6\end{array}$ & $\begin{array}{l}163 \\
124\end{array}$ & $\begin{array}{l}56.8 \\
43.2\end{array}$ & $\begin{array}{l}66 \\
39\end{array}$ & $\begin{array}{l}62.9 \\
37.1\end{array}$ & $\begin{array}{l}28 \\
36\end{array}$ & $\begin{array}{l}43.7 \\
56.3\end{array}$ & 5.962 & $0.05^{*}$ \\
\hline
\end{tabular}

Table (5): Distribution of the women according to attitude towards emergency contraception methods.

\begin{tabular}{|c|c|c|c|c|c|c|}
\hline \multirow{3}{*}{ Opinions } & \multicolumn{6}{|c|}{ Attitude $(\mathrm{N}=456)$} \\
\hline & \multicolumn{2}{|c|}{ Agree } & \multicolumn{2}{|c|}{ Neutral } & \multicolumn{2}{|c|}{ Disagree } \\
\hline & No & $\%$ & No & $\%$ & No & $\%$ \\
\hline $\begin{array}{l}\text { 1. Find that using emergency contraception is necessary in } \\
\text { the event of unprotected sexual intercourse. }\end{array}$ & 330 & 72.4 & 81 & 17.8 & 45 & 9.8 \\
\hline 2. Feel that emergency contraception is safe to use. & 116 & 25.4 & 106 & 23.3 & 234 & 51.3 \\
\hline $\begin{array}{l}\text { 3. Advice another women to use emergency } \\
\text { contraception. }\end{array}$ & 294 & 64.5 & 100 & 21.9 & 62 & 13.6 \\
\hline $\begin{array}{l}\text { 4. Emergency contraception will cause more sexually } \\
\text { transmitted diseases due to decreased usage of condom. }\end{array}$ & 74 & 16.2 & 98 & 21.5 & 284 & 62.3 \\
\hline 5. Emergency contraception is effective. & 212 & 46.5 & 119 & 26.1 & 125 & 27.4 \\
\hline $\begin{array}{l}\text { 6. If emergency contraceptions readily available it will } \\
\text { promote irresponsible sexual behavior. }\end{array}$ & 88 & 19.3 & 194 & 42.5 & 174 & 38.2 \\
\hline
\end{tabular}




\begin{tabular}{|c|c|c|c|c|c|c|}
\hline 7. Emergency contraceptions promote promiscuity. & 45 & 9.8 & 154 & 33.8 & 257 & 56.4 \\
\hline 8. Emergency contraception should be easily accessible. & 189 & 41.4 & 193 & 42.4 & 74 & 16.2 \\
\hline 9. Emergency contraception should be inexpensive. & 294 & 64.5 & 60 & 13.1 & 102 & 22.4 \\
\hline $\begin{array}{l}\text { 10. Emergency contraception should be available to all } \\
\text { women not only the victims of rape. }\end{array}$ & 258 & 56.6 & 139 & 30.5 & 59 & 12.9 \\
\hline $\begin{array}{l}\text { 11. Emergency contraception should be available without } \\
\text { prescription. }\end{array}$ & 265 & 58.1 & 80 & 17.5 & 111 & 24.3 \\
\hline $\begin{array}{l}\text { 12. Emergency contraception should be available to } \\
\text { women over } 18 \text { years of age. }\end{array}$ & 238 & 52.2 & 74 & 16.2 & 144 & 31.6 \\
\hline $\begin{array}{l}\text { 13. Emergency contraception might affect pregnancy in the } \\
\text { future. }\end{array}$ & 189 & 41.4 & 70 & 15.4 & 197 & 43.2 \\
\hline $\begin{array}{l}\text { 14. Emergency contraception might be harmful to the } \\
\text { body. }\end{array}$ & 201 & 44.1 & 47 & 10.3 & 208 & 45.6 \\
\hline
\end{tabular}

Table (6): the relationship between sociodemographic characteristics of the women and their level of attitude about emergency contraception methods.

\begin{tabular}{|c|c|c|c|c|c|c|c|c|}
\hline \multirow{3}{*}{$\begin{array}{l}\text { Sociodemographic } \\
\text { characteristics }\end{array}$} & \multirow{2}{*}{\multicolumn{2}{|c|}{ Total No }} & \multicolumn{4}{|c|}{ Attitude } & \multirow[t]{3}{*}{$\mathrm{X}^{2}$} & \multirow[t]{3}{*}{ P.value } \\
\hline & & & \multicolumn{2}{|c|}{ Positive } & \multicolumn{2}{|c|}{ Negative } & & \\
\hline & $\begin{array}{c}n= \\
456\end{array}$ & $\%$ & $\begin{array}{c}n= \\
244\end{array}$ & $\%$ & $\begin{array}{r}n= \\
212\end{array}$ & $\%$ & & \\
\hline \multicolumn{9}{|l|}{ 1. Age } \\
\hline - $<20 \mathrm{yrs}$ & 60 & 13.2 & 25 & 10.2 & 35 & 16.5 & & \\
\hline - $20-25 \mathrm{yrs}$ & 101 & 22.1 & 53 & 21.7 & 48 & 22.6 & \multirow{4}{*}{4.746} & \multirow{4}{*}{0.314} \\
\hline - $26-30 \mathrm{yrs}$ & 115 & 25.2 & 66 & 27.0 & 49 & 23.1 & & \\
\hline - $31-35 \mathrm{yrs}$ & 83 & 18.2 & 48 & 19.7 & 35 & 16.5 & & \\
\hline - $>35 \mathrm{yrs}$ & 97 & 21.3 & 52 & 21.3 & 45 & 21.2 & & \\
\hline \multicolumn{9}{|l|}{ 2. Residence } \\
\hline - Urban & 206 & 45.2 & 114 & 46.7 & 92 & 43.4 & 0.506 & 0.477 \\
\hline - Rural & 250 & 54.8 & 130 & 53.3 & 120 & 56.6 & & \\
\hline \multicolumn{9}{|l|}{ 3. Level of educational } \\
\hline - Illiterate & 54 & 11.8 & 10 & 4.1 & 44 & 20.8 & & \\
\hline - Read and write & 84 & 18.4 & 16 & 6.6 & 68 & 32.1 & 121.989 & $<0.001^{* *}$ \\
\hline - Secondary & 186 & 40.8 & 105 & 43.0 & 81 & 38.2 & & \\
\hline - University or higher & 132 & 28.9 & 113 & 46.3 & 19 & 9.0 & & \\
\hline \multicolumn{9}{|l|}{ 4. Occupation } \\
\hline - House wife & 257 & 56.4 & 133 & 54.5 & 124 & 58.5 & 0.731 & 0.392 \\
\hline - Employed & 199 & 43.6 & 111 & 45.5 & 88 & 41.5 & & \\
\hline
\end{tabular}

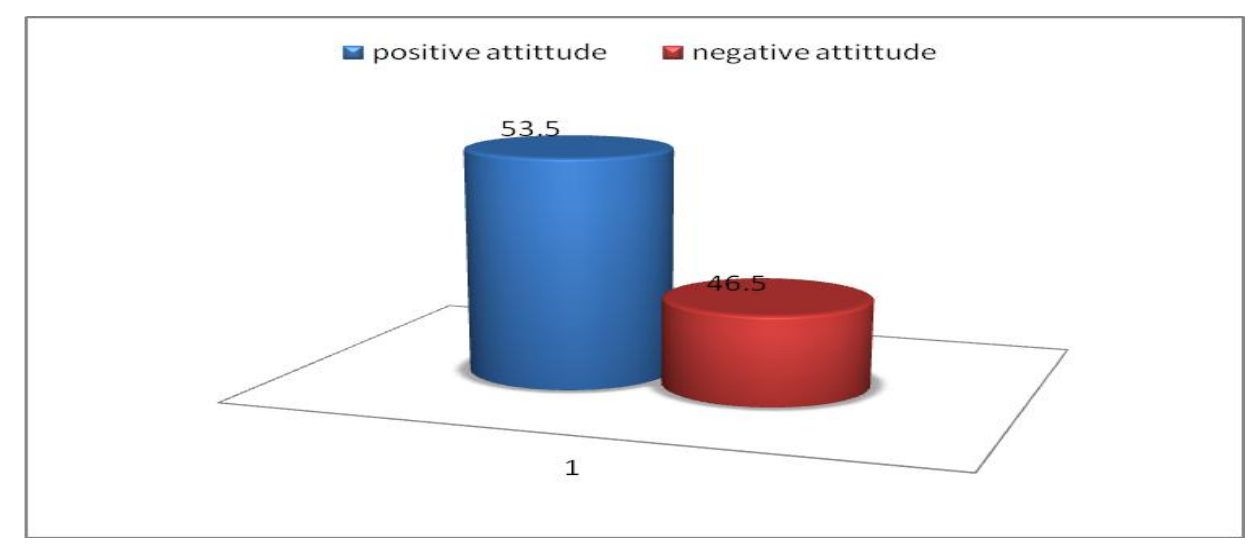

Figure(2): the distribution of the women according to their level of attitude toward emergency contraceptive methods 


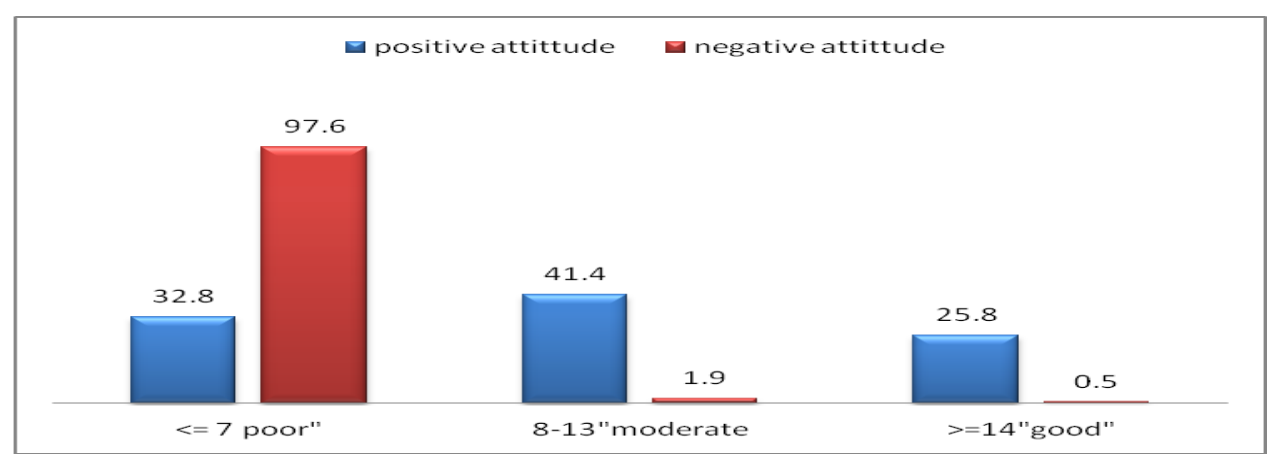

Figure (3) relationship between the knowledge and attitude toward emergency contraceptive methods.

Table (1): Shows the mean age and SD of women it was $28.00 \pm 5.84$ years. Regarding place of residence, more than half $(59.7 \%)$ of the women were living in rural areas. Concerning mother's education it is obvious that more than quarter of the studied women $(38.0 \%)$ had secondary education. Regarding mother's occupation more than half $(56.8 \%)$ of the women was housewife.

Table (2): Shows 456 (76\%) reported that they had heard about emergency contraception. Only those women who had heard regarding EC were further analyzed for asked about their awareness and attitude. Near than two third of women in this study had knowledge from family and friends. The minority of the women knew the mechanism of action of EC. The minority of the women knew when EC is generally recommended, while $212(46.5 \%)$ knew that oral contraceptives can be used as EC. 42 (9.2\%) knew that EC could be taken up to 72-120 hours after unprotected sex. More than one third of the women knew the number of doses recommended from ECPs. Less than third of the women knew the interval between doses of ECPs. More than one third of the women emphasized that ECPs act as an abortifacient drug. Only $76(16.7 \%)$ knew that $\mathrm{Cu}-\mathrm{T}$ is used as EC. Table (3): Shows that the majority $(62.9 \%)$ of them had poor knowledge about emergency contraception methods.

Table (4): Shows there were statistically significance different $(\mathrm{p}<0.05)$ between the levels of knowledge of the women and their residence and occupation. More than half $(56.3 \%)$ of the women who lived in the urban areas were employed and had a good knowledge and there were highly statistically significance difference $(\mathrm{p}<0.001)$ between the knowledge of the women and their level of education in which more than two third $(70.3 \%)$ of the university educated women had a good knowledge about it.

Table (5): Shows the women attitude toward emergency contraception methods. The majority of the women agreed to use EC after unprotected sexual intercourse. More than half of them agreed that emergency contraception is safe to use and near than two third of them replied that they might give advice to their close friends to use ECs when they faced unintended sexual intercourse.

Near half of the women were agreed that ECs is effective, the minority of them agreed that EC will promote irresponsible sexual behavior if it becomes readily available, more than half of them disagreed that emergency contraception will lead to promiscuity, more than third of them agreed that emergency contraception should be easily accessible, More than half agreed that emergency contraception should be inexpensive, available to all women not only the victims of rape, and should be available without prescription $(52.2 \%)$ of them agreed that emergency contraception should be available to women over 18 years of age, (41.4\%) agreed that emergency contraception might affect pregnancy in the future and $(44.1 \%)$ of them disagreed that emergency contraception might be harmful to the body.

Table (6): Shows that there were no statistically significance different ( $p>0.05)$ between the women attitude and age, occupation and residence. There were highly statistically significance different $(\mathrm{p}<$ 0.001 ) between the women attitude and their level of education in which $(46.3 \%)$ and $(43.0 \%)$ who had a positive attitude toward emergency contraception had university and secondary education respectively.

Figure (1): Emphasize that more than two third $(67.0 \%)$ of the women had unwanted pregnancy.

Figure (2): Shows the attitude toward emergency contraceptive methods more than half $(53.5 \%)$ of the women had a positive attitude toward emergency contraception.

Figure (3): Shows that the majority of women $(97.6 \%)$ who had poor knowledge also had negative attitude toward using emergency contraception. 


\section{Discussion}

Emergency contraception is relatively safe with no contraindication except pregnancy. It is ineffective if the woman is pregnant. There is no need for a medical history or a physical examination before providing emergency contraceptive pills. They are taken long before organogenesis starts so they should not have teratogenic effect (Veljkovic, et al., 2007).

The present study showed that about half of the women were in early adult. This were come in accordance with (Rahman et al., 2014) they performed the study in Bangladesh about "contraceptive practice among married women"

Near half of the women were employed this result was not in accordance with (Kose et al., 2012) they noticed that the minority of the women were employed. The possible reason may be related to the lower socioeconomic status of people in Upper Egypt so women work to help their husbands and improve their socioeconomic status.

As regard educational level the majority of the women were literate. This was agreed with (Kose et al., 2012) they mentioned that the majority of the women were literate with educational level of primary and above.

More than quarter of the women had university education but this was disagreed with (El-Sabaa et al., 2013) they performed their study in Alexandria, Egypt about "the awareness and use of emergency contraception among women of childbearing age" and found that the percent of women who had university education was more than half. The possible reason may be due to the lower socioeconomic status in Upper Egypt so most people didn't educate their girls to reach the university stage.

As regard residence more than third of the women were from urban areas but this was disagreed with (El-Sabaa, et al., 2013) they noticed that more than half of the women lived in urban areas. The possible reason may be related to the nature of Upper Egypt most of its areas were rural.

The present study showed that more than three quarters of women had heard about emergency contraception this was agreed with (Schwarz et al., 2007) they performed their study in California about the "'knowledge and access to emergency contraception" and indicated that the majority of the women had heard about emergency contraception

The present study showed that the main source of information was from family and friends, media followed by the health personnel (doctors, nurses and Pharmacists), this agreed with (Melkam et al., 2015) they done the study in Ethiopia about ' knowledge and practice on emergency contraceptives among females who Came for Abortion" and noticed that their source of information from friends.

The present study showed that near than half of the women mentioned that pills can be used as emergency contraception which was lowered than Ethiopian study done by (Tamire, et al., 2007) about 'Knowledge, attitude, and practice on emergency contraceptives among female University students"

Near than half of the students knew when emergency contraception is generally recommended that was noticed by (Relwani, et al., 2012) but this was higher than the current study which revealed that the minority of the women knew when emergency contraception is recommended. This may be related to the differences in educational levels between the university students and the women of the current study.

Also minority of the women knew that both contraceptive pills \& CU- IUDs can be used as an emergency contraception and this agreed with (Melkam et al., 2015). While more than third of the women knew the recommended doses of ECPs and more than quarter of them knew that it should be taken 12 hours apart which was agreed with (Mohammed et al., 2015). Also the minority of the woman knew that emergency contraception pills can work up to 120 hours and this results agreed with (Chavuma et al., 2010) but it was contradicting with (Relwani et al., 2012) they noticed that more than two third of the students knew that EC could be taken up to 72-120 hours after unprotected sex this may be related to the differences in educational levels between the university students and the women of the current study.

Regarding the mechanism of action it was noticed that more than half of the women didn't known its mechanism of action and near than quarter of the women emphasize that emergency contraception is act as abortifacient drug and this agreed with (ElSabaa et al., 2013) and agreed with (Relwani et al., 2012) \& (Khan et al., 2015) who done a study on Pakistan about 'emergency contraception: an overview among users".

Considering the barrier against the use of emergency contraception: results of this study came in line with previous studies which revealed that many women among those ever heard about emergency contraception had the misconception that emergency contraception is an abortifacient (Aksu et al., 2010). Knowing that contraception is accepted but abortion is not accepted in the Egyptian society because of religious beliefs, for example that life begins once fertilization occurs ( El Hamri 2010) (Weisberg et al., 2009) it is assumed that many people may have those religious objections toward using EC, mixing between abortion and emergency contraception as 
abortifacient. So, this issue should be considered when planning the educational materials about emergency contraception, and should particularly be addressed and made clear.

The minority of the women knew that $\mathrm{Cu}-\mathrm{T}$ can be used as EC and this is agreed with (Relwani et al., 2012). The majority of the women had lack of knowledge about emergency contraception and this results came in accordance with (Relwani et al., 2012) also these findings came in accordance with the data from other Arabic countries like Kuwait (Marafie et al., 2007) they done a study about ", awareness of hormonal emergency contraception among married women in Kuwait"' but this results contradict those of the developed country (Langille et al., 2000) they done a study about 'Knowledge and use of emergency postcoital contraception by female students at high school in Nova Scotia.

This may be related to the presence of more advanced materials which used to learn women about modern contraception including emergency contraception also developed countries concerned with continuous programs to counsel and educate women about family planning methods so women in developed countries had more knowledge than in developing countries

The present study revealed that the minority of the women had a good knowledge about emergency contraceptives and this agreed with (Lakkawar et al., 2014) who done a study in India about "'Assessment of knowledge and practice of contraceptives among women in reproductive age',

The present study revealed that a highly statistically significance difference founded between the level of knowledge and education $(\mathrm{P}<0.001)$ in which near than three quarters of women who had a good knowledge about emergency contraception had also university education. Also there was a statistically significance difference $(\mathrm{P}<0.05)$ between the level of knowledge and residence in which more than half of women lived in urban areas had a good knowledge about emergency contraception than women lived in rural areas. This finding agreed with (Myer et al., 2007). This may be related to: a. The women with a higher level of education and who live in urban areas had the greatest levels of emergency contraception awareness because theses may get reproductive health information from different sources other than public health clinics. b. Also educated women may have a greater incentive to obtain information on strategies to delay childbearing ، and thus seek out information for themselves about options such as emergency contraception.

As regards occupation there was a statistically significance difference $(\mathrm{P}<0.05)$ between the level of knowledge and occupation in which more than half of employed women had a good knowledge about EC. Also regarding the relationship between the age and the level of knowledge there was no statistically significance difference $(\mathrm{P}>0.05)$ and this agreed with (Kose, et al., 2012).

The present study revealed that the majority of the women agreed to use EC after unprotected sexual intercourse this is come in accordance with (Tesfa et al., 2015) who done a study in Ethiopia about ' 'assessment of knowledge, attitude and practice towards emergency contraceptive methods among female students" also agreed with (Worku, 2012) who done a study in Ethiopia about 'Knowledge, attitude and practice of emergency contraceptives among female college students, Southern Ethiopia and found that the majority of them agreed to use EC after unprotected sexual intercourse

More than half of them agreed that emergency contraception is safe to use and near than two third of them replied that they might give advice to their close friends to use ECs when they faced unintended sexual intercourse and this agreed with (Tesfa et al, 2015) Near than two third of women disagreed with the likely prevalence of STDs when the usage ECs increased in society and it agreed with (Worku, 2012).

Near half of the women were agreed that ECs is effective, the minority of them agreed that EC will promote irresponsible sexual behavior if it becomes readily available, more than half of them disagreed that emergency contraception will lead to promiscuity, more than third of them agreed that emergency contraception should be easily accessible, more than half agreed that emergency contraception should be inexpensive, available to all women not only the victims of rape, and should be available without prescription, more than half of them agreed that emergency contraception should be available to women over 18 years of age, more than one third of them agreed that emergency contraception might affect pregnancy in the future and more than one third of them of them disagreed that emergency contraception might be harmful to the body.

The present study revealed that more than half of the women $(53.5 \%)$ had a positive attitude toward it and this result was agreed with (Tesfa et al., 2015).

The present study revealed that a highly statistically significance different $(\mathrm{p}<0.001)$ between the women attitude and level of education in which near half of those who had positive attitude toward emergency contraception has university education.

The present study revealed that a highly statistically significance different $(\mathrm{p}<0.001)$ between the women knowledge and attitude toward emergency contraceptive methods more than two third of the women who had good knowledge also had positive 
attitude toward emergency contraceptive and this was agreed with (Kongnyuy et al., 2007) stated that those with adequate knowledge generally showed a positive attitudes regards it $(\mathrm{p}=0.000)$ also agreed with (Bugssa et al., 2014) who done a study about ", factors associated with knowledge, attitude and practice towards emergency contraception among female clients" and noticed that those who were knowledgeable have almost 3 times more likely positive attitude towards EC than their counterparts.

\section{Conclusion}

The present study concluded that in spite of a greater percentage of women heard about emergency contraception they had a poor knowledge about it. Near half of the studied women had a positive attitude regarding emergency contraception methods.

\section{Recommendation}

There is a need to raise awareness about emergency contraceptives as an option with other contraception methods and revitalizing of the family education program for disseminating similar information.

\section{Acknowledgements}

We would like to express our deep appreciation to all patients who participate in the study. Also thank the medical and nursing staffs who participate in highlighting the aims of this research

\section{References}

5. Aksu, H., Küçük, M., Karaöz, B., \& Ünay, V., (2010): Knowledge, practices, and barriers concerning the use of emergency contraception among women of reproductive age at a university hospital of Aydin, Turkey. Archives of gynecology and obstetrics, 282(3), pp.285292.

6. Bradley, S., Croft, T., \& Rutstein, S., (2011): The impact of contraceptive failure on unintended births and induced abortions: estimates and strategies for reduction. ICF Macro.

7. Bugssa, G., Kahsay, T., Asres, A., Dimtsu, B., \& Tsige, Y., (2014): Factors Associated with Knowledge, Attitude and Practice towards Emergency Contraception among Female Clients of Ethiopian Immigration and Nationality Affairs Office. Journal of Community Medicine \& Health Education, 2014.

8. Chavuma, N.., Chanda, D., \& Vwalika, B., (2010): Emergency Contraception Among Women With Abortion At University Teaching Hospital In Lusaka, Zambia. Medical Journal of Zambia, 37(4), pp.240-245.
9. Cheng, L., Gülmezoglu, A., Piaggio, G., Ezcurra, E., \& Van Look, P., (2008): Interventions for emergency contraception (Review). The Cochrane Library.

10. Dabash, R., \& Roudi-Fahimi, F., (2008): Abortion in the middle east and north africa. Washington, DC: Population Reference Bureau.

11. Dunn, S., Guilbert, E., Lefebvre, G., Allaire, C., Arneja, J., Birch, C., \& Grant, L., (2003): Emergency contraception. Journal of obstetrics and gynaecology Canada: JOGC $=$ Journal d'obstetrique et gynecologie du Canada: JOGC, 25(8), 673-9.

12. Ebuehi, O., Ebuehi, O., \& Inem, V., (2006): Health care providers' knowledge of, attitudes toward and provision of emergency contraceptives in Lagos, Nigeria. International family planning perspectives, 89-93.

13. El Hamri, N., (2010): Approaches to family planning in Muslim communities. Journal of Family Planning and Reproductive Health Care, 36(1), pp.27-31.

14. El-Sabaa, H., Ibrahim, A., \& Hassan, W., (2013): Awareness and use of emergency contraception among women of childbearing age at the family health care centers in Alexandria, Egypt. Journal of Taibah University Medical Sciences, 8(3), 167-172.

15. Glasier, A., Gülmezoglu, A., Schmid, G., Moreno, C., \& Van Look, P., (2006): Sexual and reproductive health: a matter of life and death. The Lancet, 368(9547), 1595-1607.

16. Kang, H., \& Moneyham, L., (2008): Use of emergency contraceptive pills and condoms by college students: A survey. International journal of nursing studies, 45(5), 775-783.

17. Kazi, A., (2000): Private Practitioners Practices, Knowledge and Beliefs regarding Contraception: Proceedings. In 14th Research Seminar on Population Welfare, National Research Institute of Fertility Control (pp. 166-93).

18. Khan, S., Hafeez, H., \& Akbar, R., (2015): Emergency contraception: An overview among users. Journal of Ayub Medical College, Abbottabad: JAMC, 27(1), 51.

19. Kongnyuy, E., Ngassa, P., Fomulu, N., Wiysonge, C., Kouam, L., \& Doh, A., (2007): A survey of knowledge, attitudes and practice of emergency contraception among university students in Cameroon. BMC Emergency Medicine, 7(1), 1.

20. Kose, V., \& Joshi, S., (2012): Knowledge of emergency contraception among married women of reproductive age in a rural based teaching hospital of Nagpur, Maharashtra. India. JSAFOG, 4(2), 106-9. 
21. Lakkawar, N., Nivedhana Arthi, P., Jayavani, R., L., \& Shally Magon, P., (2014): Assessment of knowledge and practice of contraceptives among women in reproductive age attending outpatient department at a sub-urban centre in Pondicherry, India. India Indian Journal of Basic and Applied Medical Research, 4(1), 196-209.

22. Langille, D., \& Delaney, M., (2000): Knowledge and use of emergency postcoital contraception by female students at a high school in Nova Scotia. Canadian journal of public health, 91(1), 29.

23. Langston, A., (2010): Emergency contraception: update and review. In Seminars in reproductive medicine (Vol. 28, No. 2, pp. 95-102).

24. Marafie, N., Ball, D., \& Abahussain, E., (2007): Awareness of hormonal emergency contraception among married women in a Kuwaiti family social network. European Journal of Obstetrics \& Gynecology and Reproductive Biology, 130(2), 216-222.

25. Melkam, M., Teklemariam, G., Abrha, S., \& Kahsu, M., (2015): Knowledge and Practice on Emergency Contraceptives among females who Came for Abortion at Mekelle General Hospital, Mekelle, Ethiopia International Journal of Medicine and Nanotechnology Volume 2 (2), 2015, Page-234-239 e ISSN - 2394-4269 Access online at www.medtechnano.com

26. Mohammed, T., Teshale, C., Musa, S., \& Gedamu, S., (2015): the effect of emergency contraception use on condom use: a cross sectional survey among students of Jimma technical and vocational training college, Jimma, Ethiopia international journal of pharma sciences and research (IJPSR) Vol 6 No 02 Feb 2015

27. Myer, L., Mlobeli, R., Cooper, D., Smit, J., \& Morroni, C., (2007). Knowledge and use of emergency contraception among women in the Western Cape province of South Africa: a crosssectional study. BMC women's health, 7(1), 1.

28. Rahman, M., Rahman, M., Huq, S., \& Hossain, S., (2014). Contraceptive practice of Married women: experience from a rural community of Bangladesh.

29. Relwani, N., Saoji, A., Kasturwar, N., Nayse, J., Junaid, M., \& Dhatrak, P., (2012): Emergency Contraception: Exploring the knowledge, attitude and practices of engineering college girls in Nagpur district of central India.National Journal of Community Medicine, 3(1), 14-19.

30. Schwarz, E., Reeves, M., Gerbert, B., \& Gonzales, R., (2007): Knowledge of and perceived access to emergency contraception at two urgent care clinics in California. Contraception, 75(3), 209-213.

31. Tamire, W., \& Enqueselassie, F., (2007): Knowledge, attitude, and practice on emergency contraceptives among female university students in Addis Ababa, Ethiopia. Ethiopian Journal of Health Development, 21(2), 111-116.

32. Tesfa A., Bizuneh A., Tesfaye T., Gebru A., Ayene Y., \& Tamene B., (2015). Assessment of Knowledge, Attitude and Practice Towards Emergency Contraceptive Methods Among Female Students in Seto Semero High School, Jimma Town, South West Ethiopia. Science Journal of Public Health. Vol. 3, No. 4, 2015, pp. 478-486.

33. Trussell, J., Raymond, E., \& Cleland, K., (2014): Emergency contraception: a last chance to prevent unintended pregnancy. Contemp. Readings L. \& Soc. Just., 6, 7 ..

34. United Nations (2012): 'Programme of Action of the International Conference on Population and Development' paragraph 7.3, accessed at www.unfpa.org/public/home/sitemap/icpd/Intern ational-Conference-on-Population-and-

Development/ICPD-Programme, on May 14, 2012.

35. United Nations Millennium Development Goals (UNMDGs)., (2012). Accessed at www.un.org/millenniumgoals/, on May 16, 2012.

36. Veljkovic, M., Popovic, J., \& Pantic, D., (2007): Emergency contraception, Acta Medica Medianae 2007,Vol.46

37. Weisberg, E., \& Fraser, I., (2009): Rights to emergency contraception. International Journal of Gynecology \& Obstetrics, 106(2), 160-163

38. Worku, A., (2012): Knowledge, attitude and practice of emergency contraceptives among female college students in Arba Minch Town, Southern Ethiopia. Ethiopian Journal of Health Development, 25(3), 176-183.

39. World Health Organization. (2011): Unsafe abortion: global and regional estimates of incidence of unsafe abortion and associated mortality in 2008. 